Papiers de Recherche du CSI - CSI Working Papers Series

$N^{\circ} 029$

2013

The performance of authority in organizations: an example from management consulting

\author{
Alaric Bourgoin \\ Centre de Sociologie de l'Innovation, Mines ParisTech \\ alaric.bourgoin(a)mines-paristech.fr \\ Nicolas Bencherki \\ Polytechnic Institute of New York University \\ nbencherki(a)poly.edu
}

Centre de Sociologie de L'INNOVATION

MINES PARISTECH / CNRS UMR 7185

60 Boulevard Saint-Michel

75272 Paris cedex 06 FRANCE

http://www.csi.mines-paristech.fr/ 
Cette collection a pour but de rendre aisément disponible un ensemble de documents de travail et autres matériaux de discussion issus des recherches menées au CSI (CENTRE DE SOCIOLOGIE DE L'INNOVATION).

Tous les droits afférant aux textes diffusés dans cette collection appartiennent aux auteurs.

Des versions ultérieures des papiers diffusés dans cette collection sont susceptibles de faire l'objet d'une publication. Veuillez consulter la base bibliographique des travaux du CSI pour obtenir la référence exacte d'une éventuelle version publiée.

CSI WORKING PAPERS SERIES

The aim of this collection is to make easily available a set of working papers and other materials for discussion produced at the CSI (CENTRE DE SOCIOLOGIE DE L'INNOVATION).

The copyright of the work made available within this series remains with the authors.

Further versions of these working papers may have been submitted for publication. Please check the bibliographic database of the CSI to obtain exact references of possible published versions. 


\title{
The performance of authority in organizations: an example from management consulting
}

\author{
Alaric Bourgoin \\ Ph.D. candidate, Center for the Sociology of Innovation, Mines ParisTech \\ alaric.bourgoin@mines-paristech.fr
}

Nicolas Bencherki, Ph.D.

Postdoctoral fellow, the Polytechnic Institute of New York University

nbencherki@poly.edu 


\begin{abstract}
:
In this paper, we sketch a pragmatist model of authority. We show that, as authority is concretely performed through interaction, it contributes to the constitution of organizational boundaries. Through the case of a six-month consultancy assignment at a large French energy group, our study highlights that authority is not only the result of a mandate or a particular endowment of the consultant, but has constantly to be established as everyday work unfolds. We argue that a consulting assignment involves a large share of ambiguity which, while being a source of uncertainty, also allows the consultant to position himself as acting on behalf of a variety of figures that lend weight to his actions and authorize them. We identify three different forms that these figures can take: people, material artifacts and abstract entities. Finally, we show that it is the mobilization of some figures rather than others that situates the consultant either within or outside organizational configurations, thus allowing him to tactically act as an outsider or an insider.
\end{abstract}

Keywords: Authority, Boundaries, Consultancy, Ethnography, Client relationship. 


\section{Introduction}

While power and authority are central to organizational life, few studies look at the concrete practices through which authority is performed. In this paper, we use an ethnographic perspective to study the relationship between the situated, pragmatic performance of authority and the process of boundary-constitution in organizations. By looking at the case of a consultant faced with the issue of establishing his authority in the actual context of a consulting assignment, we uncover how the consultant invokes various "figures" that lend weight to his actions (BenoitBarné \& Cooren, 2009; Cooren, 2010). The notion of figures designates any elements, independently of their nature, that may play a part in an interactional scene. Said otherwise, while the structures that grant authority to the consultant may pre-exist (education, hierarchy, knowledge, and so forth) they also have to be made present again, here and now, in order to become apparent, both to participants and to researchers. In invoking those figures, the consultant does not only constitute himself as a competent player, but also contributes to the establishment of organizational boundaries, depending on the network of adjuvants he decides to rely on.

Consultancy provides a particularly potent terrain to the study of authority, as consultancy assignments are far from being merely the execution of plans, where the consultant would carry out a pre-defined course of actions. As a colleague told Tony, the ConsultCorp consultant we will be following throughout this paper: "a well framed assignment is a big step toward success, because everyone knows what has to be done and the stages are set. This being said, the reality of the mission always catches up and brings its portion of surprises." In other words, the consultant must continuously renegotiate the mission and his ability to carry it through. As Lucy Suchman (1987) points out, while planning remains an important part of work, plans are in fact discussed and debated throughout the performance of action.

Authority and action are intimately tied together: not only does action require authority, but thinking authority is impossible without action. François Cooren $(2010$, p. 3) notes that "things as basic as authority and power cannot be really grasped and understood if some form of doing or even agency is not recognized in attributes such as experience, wisdom, expertise, or status (just to name of few of them)." This quote stresses that while experience, wisdom and other "characteristics" may play a part in establishing an individual's authority, it is not their mere existence that makes a difference: their agency must be made to count, their meaning negotiated and turned into concrete action. That is why it is not sufficient to simply insist on the contingent aspect of a consultancy mission. Research should also focus on the proactive role of the 
consultant in dealing with the mandate he was given and in using the available levers to assert his or her authority and, in doing so, shape the mission itself.

Literature on authority in the context of consultancy is, to say the least, scarce. When authority is mentioned to address consulting work, it is often in passing, to stress the importance for consultants or project managers to have sufficient authority to carry on their tasks (Gideon, Barley, \& Evans, 2002; Julian, 2008; Singh, Keil, \& Kasi, 2009). However, authority cannot be limited to the formal entitlements within the client organization. A more sophisticated understanding of authority is that of Armbrüster (2006, ch. 4). While he has the merit of being one of the few authors to consider authority in the context of consultancy work, Armbrüster's view of authority is limited to a transaction-cost and signalling perspective (see also Williamson, 1996). Consultants' authority is defined as their ability to make visible, prior to the client's decision to engage in the relationship, their skill, professionalism and other desirable features. Such as view, while being also true, limits the notion of authority to the manipulation of insignia, diplomas and other signals of authority, thus giving the impression that consultants do not actually need to possess any skill, as long as they appear to be skilled. Furthermore, it implies that authority is dealt with once for all at the moment of engagement, and leaves aside the constant renegotiation that is part of any consultant's daily work.

Rather than taking a pre-established contract or personal attributes as a starting point, we choose to focus, in our contribution, on the "cracks" where consultants can find some room to act and assert authority. In particular, we use a pragmatic vision of authority to understand how consultants can successfully provide advice that relies on a constant negotiation of their legitimacy to act. In our view, authority is not only a proof of competency or a matter of getting people to obey to one's injunctions, but also - and perhaps mostly - a matter of showing how one's action are authorized by a variety of figures that lend weight to these actions (Cooren, 2010). We will, in the following pages, introduce an analytic division of those figures into three categories: people, artifacts and abstract entities.

This vision relies on the work of Taylor and van Every (2011, forthcoming) for whom authority is built on the relation between two individuals and the organization they are contributing to. In that sense, authority is more than a personal trait; it lies in the associations one establishes with others, whether they are human beings or non-human artifacts, because, as Latour (1996, p. 237) says, "When one acts, others proceed to action". Analysing how a consultant is able to assert his authority, therefore, also means describing the accomplishment of such associations. This approach has two advantages. First, it allows accounting for moments when assertions of authority are made without being formulated as such, for people rarely say 
explicitly "I am authoritative" but will more likely state that "This is what rigorous management says we should do." Second, it allows, in line with Alvesson, Karreman, Sturdy and Handley's (2009) invitation to study consultant and client construction, to look at the way the various entities with whom action is shared are made present in the situation and made to act. This means that we will obtain a clearer picture of the way expertise, experience or education, along with mandates from executive management, agreements, or other elements, may "lend weight" (Cooren, 2010) to the consultant's actions. In other words, we will not simply postulate a relationship, but observe the minute practices by which they are translated into authority.

This paper does not intend to judge whether the practices described are useful or desirable. We share Alvesson and Johansson's (2002) caution in that we believe that both overly enthusiastic and overly critical stances on management consultancy equally fail to account for what is actually going on. While the mission we will describe was punctuated with trials and errors, "muddling through" is not the prerogative of consultancy, but rather, as Lindblom (1959) famously remarked, the very foundation of administrative science. What we do share with critical perspectives on consultancy is their concern with "how [consultants] demonstrate their value to clients in the first instance" and the "strategies employed by consultants to convince clients of the worth of their advice" (Fincham \& Clark, 2002, p. 6). Indeed, managerial literature on consultancy tends to take for granted the value of consultants and focuses on the respective efficiency of various techniques or approaches. Critical perspectives, on their part, make an important point in stressing that consultants must continuously demonstrate their skill and the value-added they provide to their clients. We depart with the critical literature, though, in that some authors associate this continuous demonstration with a form of manipulation on the part of consultants (Jackson, 1996; Clark \& Salaman, 1996), while we contend that this is a feature of any consultant's everyday work and indeed a necessity given the ambiguity of his or her positioning with respect to the organization. In other words, asserting expertise, legitimacy and authority is not a sign that there is in fact nothing behind those assertions (as if "true" expertise or authority could be self-justifying). Rather, those assertions are necessary parts of any work and are made more salient in the case of consultants because of the lack of a stable organizational repertoire of authority from which to draw - e.g. they cannot rely on their hierarchical position or on a history of interactions.

Contrary to locals, the consultant does not hold a clear and stable position in the hierarchy that provides him with institutional authority. He must constantly integrate within or circulate among new networks of interactions, which may be hostile and contribute to the challenge of his authority. In addition, he does not usually find himself in a stable physical location where he 
could create spatial routines which may serve as symbolic resources or springboards for action and we know since Garfinkel (1967) and Goffman (1969) the importance of spatial location as a frame for interaction. The consultant has to be "on-site" and circulate within the client organization. In many cases, and in particular in "project" configurations, the strategic outsider position, which for many authors is the very reason of its existence, has to be relativized. On the contrary, we felt the outsider position was in fact essentially tactical, that is to say determined by the topography of the client's field. To say it using Michel de Certeau's (1990) words, "I call strategy the calculus of force-relationships that becomes possible from the moment a subject of will and of power becomes isolatable from an 'environment' [...] I call, on the contrary tactical a calculus that cannot count on a proper, nor thus on a borderline distinguishing the other as a visible totality. It permeates into it, in a fragmented way, without embracing it in its entirety, without being able to keep it at a distance" (p. XLVI; our translation).

A contribution of our analysis is to show that the dynamic constitution of the consultant's position amounts to the negotiation and constitution of the inside/outside boundary of the consulting practice. It is that same boundary that Wright (2009) discusses as he addresses the uncertain role of internal consultants. We feel his insight, in fact, shows that the boundary between inside and outside is exactly what is at stake in consultancy projects, including the case we described, and that a priori classifying consultants as internal or external is somehow putting the cart before the horse. Wright notes that it is the very tension of their dual positioning that provides consultants with a unique autonomy and ability to "discuss taboos and confront assumed wisdom with senior and politically powerful client managers" (p. 318). He explains further that tensions for (internal) consultants exist at every level. For instance, while they are independent "from existing reporting relationships" (p. 310), internal consultants also relied upon "senior management patronage" (p. 317) to gain organizational legitimacy. Wright mentions Ganesh's (1978) highlighting of the contradiction between, on the one hand, consultants' "expert role" and "outsider stance," and on the other their "high need to belong, to be members of the client system, to be insiders" (pp. 13-14). To Wright, this is essentially a question of identity, which he documents using semi-structured interviews with individuals who self-identify as internal consultants. We argue, however, that it is also very much a question of authority, and more precisely of authority assertions.

Focusing on the situated performance, in interaction, of assertions of authority requires the level of granularity offered by equally situated ethnographic observations. Thus, our approach is based on a participant observation, where one of the authors became involved, as a professional consultant, with a large French energy group. During the six-month mission, he had to help the 
integration of a newly-acquired subsidiary and had a privileged access to the daily reality of a large-scale restructuring process. Consistently with the conception of authority we adopt, the analysis will be based on the detailed observation of the way the consultant and other players invoke various figures, through talk or through different practices. This is why our analysis is attentive to situations where authority is controversial. Focusing on moments of uncertainty follows the intuition developed in science and technology studies (Latour, 2005, Part I; Callon, Lascoumes, \& Barthe, 2009) that it is at those times that the truths that had been "black boxed" are unfolded again and made available for debate. A similar argument was made by Garfinkel (1967, p. 36) concerning the need to reveal the "socially standardized and standardizing, 'seen but unnoticed,' expected, background features of everyday scenes." In our case, the consultant, by having to establish his authority, is showing participants, but also researchers, for "another first time" (Garfinkel, 1967, p. 9) how his mandate, his clients, his knowledge of the field, his experience, and other figures assemble to constitute him as an authoritative expert.

In the next section we propose a literature review on the notion of authority using inputs from sociology, organization science and communication theory. Specifically, we sketch a pragmatist approach to understanding authority as a performance. The third section of this paper is dedicated to methodological aspects of the research. The case we focus on is described afterwards and followed by the analysis. We then discuss, among other things, how the consultant, in invoking some figures rather than others as the source of his authority, is positioned inside or outside the organization. This implies that authority plays a part in other organizational processes, such as boundary negotiation. Finally we conclude by providing reflections for further research.

\section{The notion of authority}

Authority has been variously defined and all authors do not agree on its core features. The notion, in many research papers, is conceptualized from a principal-agent model (Grossman \& Hart, 1983), where the issue is framed around the ability of a person to get someone else to carry out a set of tasks on his or her behalf (see for example Aghion \& Tirole, 1997; Dessein, 2002). This conception does capture a basic feature of authority: that it involves more than one actor, i.e. a relationship. However, it locates, too hastily, authority only on the side of the principal, while the agent is presented mostly as passive and as needing incentives in order to act.

In our view, reducing action to a problem of incentives causes several problems. First, as notes Kuhn (2008; Kuhn \& Lee Ashcraft, 2003), it supposes a purely contractual and rational 
relationship, which may omit, for example, other motivations for work, including passion (Forest, Mageau, Sarrazin, \& Morin, 2011; Cooren, 2010). Baker, Gibbons and Murphy (1999) also question the possibility of reducing authority to contracts and point to the importance of communication in allowing informal authority. Finally, another problem of the principal-agent model is that it supposes that the relationship is negotiated once for all at the moment of engagement.

In the next section, we sketch a different understanding of authority. Our framework does not oppose existing literature. Rather, it relies both on a re-reading classic works, including those of Max Weber and Chester Barnard, and on developments from authors of the Montreal School of organizational communication (for an outline, see Brummans, 2006) which, we will see, are very much compatible as they all leave room for interaction and pragmatics. Indeed, in Weber's or Barnard's views, authority is not only about delegation or control, but also about negotiation, acceptation and, ultimately, shared action.

\section{The negotiated character of authority}

One cannot mention authority without paying homage to Max Weber. The German sociologist is mostly remembered among organization and management scholars for his distinction of three kinds of legitimate domination: the rational-legal, traditional and charismatic types. Along with the principal-agent model, Weber's types are common ground in discussions of organizational authority (Satow, 1975; Nelson, 1993; Hoogenboom \& Ossewaarde, 2005; Lounsbury \& Carberry, 2005). The types are however often mentioned out of context and reduced to their simplest characteristics. We do not have the leisure here to write in extended detail about Weber's conception of authority, but some important features are to be noted. As early as the first few lines of the third chapter of Economy and Society (1968, p. 212), Weber notes that "every genuine form of domination implies a minimum of voluntary compliance, that is, an interest (based on ulterior motives or genuine acceptance) in obedience." That is what he calls legitimacy, which is, to him, the flip side of "Domination ('authority')." Weber goes on explaining that authority cannot be exerted on a purely material or economic basis, and even affection or ideals cannot suffice: "in no instance does domination voluntarily limit itself to the appeal to material or affectual or ideal motives as a basis for its continuance. In addition every such system attempts to establish and to cultivate the belief in its legitimacy." (p. 213).

Weber's conception of authority, therefore, cannot be divorced from the notion of legitimacy. And to him, this legitimacy implies a form of interest on the part of the subordinate, an interest that cannot be limited to economic concerns. Weber therefore makes us wonder: what 
are the interests that lead people to accept authority? This question does not appear to us to be clearly settled and may, in fact, prove useful given our own focus.

Indeed, the notion of interest, while it is often understood in common language as economic interest, may be much more fruitfully thought in a broader understanding. Interest, indeed, comes from the Latin inter, meaning "between," and esse, which translates into English as "being," and therefore concerns more specifically the various things I need to sustain myself among my peers, my organization, my society, the many elements that tie me to these. If I should disregard my own interest, I may not only lose money, but also status, belonging, friends, and, in a sense, lose myself (Dean \& Massumi, 1992). This is also the case for the consultant, who needs to watch for his or her interests, not only in pecuniary terms, but also, and perhaps more importantly, in order to continue to act as a consultant, to be recognized as such, and to continue delivering services to his or her clients.

Of more obvious relevance to organization and management studies, Chester Barnard is probably, after Weber, the most common name when it comes to discussing authority in our field. Chapter XII of his iconic The Functions of the Executive (1938) is entirely devoted to sketching "The Theory of Authority." From the outset of the chapter, Barnard's definition of authority surprises by its originality: it relates to the "willingness of individuals to contribute to organizations." In other words, authority is not so much hierarchy and power, as it is about making sure that the organization is ongoing thanks to the many actions of its members. Barnard's understanding of authority is quite daring for his times, as he stresses that authority has no essential dimension - rules, laws and orders are in fact routinely ignored - but that it lies instead in people's understanding of the contribution they are asked to make. Rather than obedience, people's compliance may be better explained by indifference or alignment of interests. Thus, Barnard suggests that authority lies in the hand of those commanded: "If a directive communication is accepted by one to whom it is addressed, its authority for him is confirmed or established" (p. 163). This is also what Peter Blau (1963, p. 208; cited in Taylor \& Van Every, forthcoming) remarks: authority "depends on the willingness of [...] subordinates to obey." For Barnard, the crux of authority is action: "It is admitted as the basis of action. Disobedience of such a communication is a denial of its authority for him." Chester Barnard therefore opens the door for an understanding of authority where the attention of the researcher turns from the structures of power to the practices of men and women in the everyday settings where communication and action are negotiated. 
Barnard's understanding of authority is in agreement with Weber's. In both cases, the focus is not so much on the exertion of authority as much as it is on its reception. What we will retain more specifically from Barnard's contribution, however, is his focus on action: authority is necessary for action, and it is in fact through action that obedience or disobedience are enacted. It is important to note that authority being made apparent or present in action makes the notion observable (rather than inferable) and gives the means for an empirical approach to authority that would have been impossible otherwise.

Both Weber's and Barnard's positions open the possibility for an understanding of authority that is not unitary and homogeneous. In allowing those who "receive" authority to play a part in its expression, their views offer an account of authority where it may take different forms and be enacted in various ways.

\section{Authority and power}

Understanding this variability is easier when authority is contrasted with its close cousin, power. The theme of power in organizations has been treated extensively, for example by authors such as Dennis Mumby (1988), Mats Alvesson (1996) or Gareth Morgan in his seminal Images of organization (1986, ch. 6; see also Ailon, 2006; Dixon, 2007). In most cases, power is understood as being granted by one's position within the organization, for example because of hierarchy, because of a knowledge imbalance or because of gender or ethnicity. Said otherwise, people speak from a position of power (or of lack thereof) ${ }^{1}$. However, we consider that this position is not only given or static, but also made available by a set of discourses and devices that do not only describe the world but indeed constitute subjects and assign them their rightful place (for a Foucaldian understanding of power and organizations, see Bergström, Hasselbladh, \& Kärreman, 2009). Power is the ability to submit other people to an apparatus that depicts and produces their allocated position (but, on position and positioning, see Harré, Moghaddam, Cairnie, Rothbart, \& Sabat, 2009). As Mumby (1998) points out, positions are real and constraining, but they are so because they were performed or constructed in the first place. Stating that the power structure is itself produced in everyday practice opens "kinks, gaps, fissures, and ruptures of various kinds" (Mumby, 1998, p. 168), so many interstices where power can be contested and negotiated, where actors can beat the system (Crozier \& Friedberg, 1980). Room can be found for a form of power that flows from people's activities along with traditional institutionalized rules and structures. In

\footnotetext{
${ }^{1}$ This is what Bourdieu suggests when he believes that Austin's speech acts theory fails to account for the institutional conditions of their felicity (Bourdieu, 1991, p. 73).
} 
support of this more fluid, composite understanding of power, Latour (1986, pp. 264-265) points out:

The problem of power may be encapsulated in the following paradox: when you simply have power - in potentia - nothing happens and you are powerless; when you exert power - in actu - others are performing the action and not you. [...] Power is not something you may possess and hoard. Either you have it in practice and you do not have it - others have - or you simply have it in theory and you do not have it. What makes the difference between power 'in potentia' and power 'in actu'? The actions of others. Power over something or someone is a composition made by many people.

This wavering, negotiated power is what we call authority.

Reinhard Bendix (1956) is one of the rare critical authors who used authority, rather than power, as his entry point. In line, for example, with Weber, the Marxist sociologist of organizations notes that while people higher in the bureaucratic hierarchy may have an "overview" of the work to be done, "subordinates tend to acquire power even without authority to the extent that their expertise removes them from the effective control of their superiors" (p. 9). In comparing Western and Eastern exercise of authority, Bendix points out that in the latter case, authority and its counterbalancing "represent [...] appeals to the workers as expressing the interests and demands of the workers themselves" (p. 10). In any situation, he points to the fact that authority must claim to be acting in the interests of others, and to gain their compliance and "good faith." This cooperation, he observes, relies on the recognition of the worker "as a responsible human being and could not be obtained as long as he was treated as a cog in the production process" (Bendix, 1947, p. 500). This acknowledgement of the need of taking into account the individual's totality, especially in a process perspective, has been pointed out more recently in other related traditions of organization studies. For example, Carr (1998) used a psychoanalytic lens to show how compliance or dissent cannot be divorced from the identitycreation practices of workers. This cooperation has also been studied from the perspective of a neighbouring concept: legitimacy. Whether from a narrative approach (Golant \& Sillince, 2007) or through the study of alternate modes of negotiating it (see the example of spirituality at work in Casey, 2004), the constitution of legitimacy is viewed as the invocation of elements (stories or workers' soul) that contribute or challenge a version of what is coherent or rational in the workplace. We contend that these disparate accounts of authority, compliance and legitimacy all share common features: a) they show that authority cannot be located only in the hands of those 
who exercise it, but that it also relies on those who obey; b) they point to the fact that many elements are missing in the analysis, which constitute the individual as an able, competent contributor to his or her organization; and c) that there is a need for a process-oriented, pragmatic perspective that looks at the unfolding of authority as a practice.

What it the relationship between power and authority? Do power structures "cause" authority (for example by leaving room for it) or is it authority that constitutes power structure over time? Perhaps it is not a decision that can be made in advance. In fact, the issue of causality is exactly at the crux of authority as a notion. For each action, its cause - or its author - is not a given, but rather a matter of debate and something that is discursively decided (Castor \& Cooren, 2006). It is always possible to go further back in the chain of agency and show that what was thought to be the cause is in fact itself caused by some further agent or event (although we acknowledge that there are many actions for which a cause may be easier to settle). Authority, then, is not self-evident in any given situation: it must be made present or "presentified" (BenoitBarné \& Cooren, 2009). This presentification is performed in speech when consultants state they are acting on behalf or for further authoritative actors (in the broad sense of the word, including education, expertise, and so forth).

A brief etymological detour is interesting here. Authority, is, according to the American Heritage dictionary, at the same time "the power... to exact obedience," "one that is invested with this power," "power assigned to another; authorization," "the expert source of information," "justification, grounds," and "confidence derived from experience." Etymologically, authority and authorization come from the same notion of authoring, i.e. being the author of something. The close relationship between these notions is at the heart of Taylor and Van Every's (forthcoming) approach to authority. If authority, as the American Heritage dictionary suggests, concerns at the same time authorization and justification, then being authorized, to some extent, is also saying because of what someone or something acts. The English word because (or the French pourquoi, Polish dlaczego, Russian почемy, which all mean why) are effective illustrations of this conception of authority: justifying oneself, that is saying why (pour quoi, literally for what; the same applies to dla czego or по чему) or be-cause of what someone or something acts, corresponds to attributing the action under investigation to other entities upward in the chain of agency. Said otherwise, it is presenting oneself as being moved or animated by those other entities and sharing one's authorship with them. I share my authorship of the action with the cause I invoke, and in a sense it is also my own position as an actor that is authored by that cause. For each action to be authoritative, therefore, one needs to distribute its authorship among other agents. 


\section{Toward a pragmatic model of authority}

The work of Taylor and van Every (and most famously Taylor \& Van Every, 2000) is mostly known in the field of organizational communication, where their contribution to the sketching of a communicative constitution of organization (CCO) approach of the relationship between communication and organization is widely acknowledged. Authority, as Taylor and Van Every point out, consists in the ability to "author" the organization, of saying what it does, what it wants, and what actions should be contributed to it. It is authority that makes what is said or done authoritative, because those actions are presented as being performed for the organization. As Taylor and van Every (forthcoming, ch. I) point out, speaking of organizational members, "It is their collective authorship that generates the narrative of an organization that then becomes their 'author,' since, once they have constructed it, it recursively (Giddens, 1984, pp. xxxi, 2-3) delegates them to do its work."

Cooren (see especially Benoit-Barné \& Cooren, 2009; Cooren, 2010) builds on Taylor and van Every's intuition and suggests that the study of action and authority consists in showing the many organizational figures that are made present to lend weight to action and make it authoritative. He borrows from the same vocabulary as Taylor and van Every (forthcoming) in connecting authority and authoring. As he explains:

lending weight to one's position consists of implicitly or explicitly showing that we are not the sole authors of what is put forward, but that other things appear to support and author it too. Staging figures in our dialogues therefore amounts to mobilizing various sources or figures of authority that constitute as many authors of one's position. It is another way to dislocate the interaction. (Cooren, 2010, p. 10)

Through interaction, individuals mobilize a variety of figures (organizations, rules, principles, documents and so forth), thus making them present and acting in the current situation. In doing so, individuals, while giving a voice to those figures and allowing them to act, also position themselves as being passively manipulated by the figures. This play being activity and passivity is what Cooren calls ventriloquism, in the sense that, similarly to what happens in a puppeteer's show, authority is established in the vacillation of the distribution of voices. The key feature of Cooren's understanding of authority lies in the shared character of action, where "ascribing authority to something or someone usually consists of identifying who or what is authoring something at a specific moment" (Cooren, 2010, p. 73). As a consequence:

We seem more powerful precisely because our actions and decisions appear to be shared with others. For instance, when an employee tells me, "According to our policy, we cannot 
provide you with this piece of information," it is as if it were not only he who was turning down my request, but also (and maybe especially) his organization (through its policy). ( $p .73$ )

In the same way as Taylor and van Every (forthcoming) stress the importance of the third, i.e. the organization, in providing people with an authoritative position from which to speak and act, Cooren further opens up the scene and includes a variety of entities (policies, documents, computers and so forth), which authorize the very individuals who mobilize them and provide them with existence in the current interaction. Discussions over authority, in that sense, are debates over the parties' ability to make those entities speak and make them support their actions.

While Taylor and van Every's approach already hints at the necessity of looking for the authoring processes, Cooren's "figurative" perspective allows looking precisely for those moments where one mobilizes principles, rules, documents and other entities to provide oneself with more authority. It follows, on that aspect, actor-network theory's (Law \& Hassard, 1999; Latour, 2005) invitation to understand action as being achieved by an association of humans and non-humans, rather than by any single individual. A similar pragmatic focus involving the application of ANT to the study of organizational and market action may be found in the works of Michel Callon and Fabian Muniesa at the Center for the sociology of innovation (Callon \& Muniesa, 2005; Muniesa, Millo, \& Callon, 2007).

\section{The performance of authority in a consulting project: an empirical study}

\section{Methods}

Our research design was established to allow a focus on consultant's assertion of authority in the actual practice of their job. In line with our pragmatic approach, the design was inspired by a range of theoretical insights such as practice-based, situated and interactionist approaches to organization studies (Gherardi, 2000; Suchman, 1987; Tyre \& von Hippel, 1997; Taylor \& Van Every, 2011; Cooren, 2007). However, direct access to consulting projects as an external observer is difficult and this is, as Sturdy and his colleagues (2009b) put it, "an important factor in the relative lack of existing data and research [...] especially beyond that obtained through interviews" (p. 47).

To overcome this difficulty, we chose to rely on ethnographic material gathered by one of the authors (whom we call Tony) through a six-month participant observation in a consultancy 
assignment, led for a major French company that we call EnergyCorp. Tony became involved in the consultancy project when the director of the MotherCompany internal consulting division, with whom he had worked in the past as an academic-consultant, contacted him to ask whether he would be interested to handle the restructuring assignment. Tony asked the other co-author to take a share in the project as an outside observer. This particular research method had the advantage to give the authors full access to the consultant's practices and at the same time allowed space to step back for analytical development. The main clients were aware of one of the author's research activity but had no interest in the results of the study

Although quite rare in the case consulting practices, ethnographies of organizations are not uncommon (other ethnographic perspectives on authority include Kahn \& Kram, 1994; Murphy, 1998), especially under the label of "workplace studies." It has been argued that, in general, the advantages of using participant observation in comparison to qualitative interviewing include: the ability to see through other's eyes, learning the native language, sensitivity to context, naturalistic emphasis, and encountering the unexpected (Bryman, 2004, pp. 338-339). The approach we adopt in this paper is to start with consultancy practices and the way consultants talk in order to describe how authority is achieved by consultants, rather than to measure the extent to which these practices are present in organizations. The question how calls for attention to the concrete ways people perform the practices under scrutiny, and ethnography offers the level of observational detail required to document these methods.

The description of those concrete practices is allowed exactly by the features of participant observation identified by Bryman (2004). "Going native," as Meunier and Vasquez (2008) call it, allows researchers to use their own familiarity with the fieldwork to ensure they recognize the practices they witness. As Garfinkel (1967) explains, participants are "skilled" at their own practices. Sociologists, in understanding these practices, should not superimpose a "professional" reading, but rather allow participants to reveal and explain the logic of their practices. By becoming skilled participants themselves, researchers can make sure they share the vocabulary and methods of the communities they observe. In our case, the duration of the consultancy mission - six months - and Tony's previous engagements as a consultant allow us to be confident about our reading of what people say and do.

In our case, access to data was warranted by regular, professional participation to consultancy assignment. The analysed material was gathered through a range of methods including document collection (emails, notes, reports, minutes, memos and so on) and participant observation in formal and informal meetings supplemented by several informal follow up interviews with the participants. In particular, a diary was kept throughout the six-month 
involvement in the assignment to describe the unfolding of the project. Field notes were taken on the spot or shortly after, depending on the situation and what seemed appropriate. We do recognise the necessarily partial aspect of ethnographic data collection. But as Whittle (2008) rightly explains in her study of consulting discourse, this type of methodology "enables the short snippets of conversation and words and phrases written in field notes (conversations were generally too fast to act as a "human tape-recorder") to be worked up into a form that resembles the author's recollection of events" (Whittle, 2008, p. 519).

We follow Anderson's (2006) belief that self-ethnography does not need to be "evocative" and can serve as a strong basis for an interaction-analytical approach. While we acknowledge the need for self-ethnographic research that "is essentially a self-report of personal experience" (Crawford, 1996), we consider our data as a recording of interactions, which we analyse as such. The role played by the second co-author is crucial in this respect for he could challenge and reframe Tony's analysis of the situation. Besides, while we are conscious of the importance of the writing process (Richardson, 2005; Goodall, 2000; Richardson \& Lockridge, 1998), we prefer, for the sake of brevity, not explicitly addressing this question at the moment.

The process of analysis broadly follows the one used by Sturdy and his colleagues (2009b) in their study of consulting "boundaries and knowledge in action," a dual process which Kvale (1996) calls "categorizing" and "condensing". One co-author took extensive field notes that the other would then summarize and condense "keeping intact some quotations but maintaining the narrative thread. The second element was thematically to categorize discrete segments of [...] observation field notes using open coding technique (Sturdy, et al., 2009b, p. 66)". The general theme of authority assertion emerged quite rapidly as the first co-author felt the challenge of his assignment was to give weight to his actions in a context of strong political tensions. Subthemes were then categorized according to (1) the nature of the interaction and the felicity of the authority assertion ("success," "failure," "active negotiation") and (2) the type of figure used by the consultant to give weight to his actions ("mandate", "abstract entity", "material artefact", "human ally"). We finally "tested" our argument on the main client and the manager at ConsultCorp during dedicated sessions. If surprised by the type of analysis, they nonetheless validated the data and the accuracy of the story, and their insights were very useful to the authors.

\section{The case}

The case we will be looking at is that of a consultancy mission provided by ConsultCorp. The firm, which comprises a hundred and fifty consultants, offers generalist management advice 
in various fields, from banking to healthcare. It specializes in "transformation" or "operational strategy" missions in which it helps executives during the implementation of long-term, complex programs. These may consist in post-merger integration, reorganization, adaptation to market deregulation and so on.

The mission we will focus on here dealt with the restructuration of a group of twenty-one firms, EnergyCorp. The group was recently acquired by a French multinational, MotherCompany, which plans to absorb it if satisfactory results can be obtained after the implementation of a three years restructuring program. To design and implement this program, MotherCompany can rely on EnergyCorp's new executive team. On top of that, MotherCompany has an internal consulting service called "the Projects Office," whose role is to assist functional directors on such type of missions requiring a specific "project methodology." With this kind of assignment, MotherCompany's Projects Office finds itself in an advisory role with respect to managers and has no immediate authority over the unfolding of the project.

Restructuring is a complex process that needs coordinated action on most levers of the organization. In EnergyCorp's case, two main stages can be distinguished: (1) MotherCompany's Projects Office conducted a concise audit at EnergyCorp and convened an executive seminar to draft a three-year plan with quantified targets. This prospective dashboard (a sort of balanced scorecard) was then translated into thirty-six different projects gathered in a general "projects plan". (2) The "projects plan" was implemented by EnergyCorp executives with the help of an outside consultant, hired by the MotherCompany's Projects Office and working in close collaboration with it. It is on this second phase that our study focuses.

Basically, the projects plan concerned all facets of the company: reorganization, people review, optimization of core and support processes, cost killing and saving, adjustments to the sales policy, adoption of a new IT system, and so on. The consultant worked alone but had at his disposal resources from the Projects Office. Furthermore, he headed a team of inside experts who intervened within their own fields. The director of MotherCompany Projects Office provided two reasons for hiring an outside consultant from ConsultCorp: the lack of resources at his office for this type of mission and his good acquaintance with the consultant, with whom he had worked on other projects and whom he "entirely trusted."

As is often the case in transformation missions, the client-system was complex. The "client" of this consultancy mission could hardly be considered unique or homogeneous (for a reconsideration of the notion of client, see Alvesson, et al., 2009). The MotherCompany Projects Office (paying client) hired a ConsultCorp consultant, who was in fact seconded to work with EnergyCorp's CEO (operational client). The Projects Office rebilled ConsultCorp's consulting 
service to EnergyCorp with a $10 \%$ markup to cover for supervision costs. In this configuration, the consultant had to account for his work to his paying client, but also to the operational client to whom he reported on a day-to-day basis. This kind of triadic relationship may become difficult to handle when oppositions surface between paying and operational clients, as was the case during this mission. In the crossfire, the consultant has to display an acute sense of diplomacy. This is especially true given that the client-system also included other interlocutors, not the least being the functional directors of EnergyCorp and other insiders, with competing interests.

The consultant was attributed tasks of two kinds: (1) steering tasks, such as the facilitation of executive committee meetings, the production of strategic coordination and projects tracking documents and so on; (2) operational tasks related to the production of deliverables for each project (organization charts, people review tool, etc.) and to the overhaul of processes. The consultant's work required him to split himself between high-value work with the executive committee and more operational tasks at the level of the middle management (thus acting both as an expert and as a "pair of hands," as per Schein, 1999). He also had to transpose executive directives on the field, convey members' concerns to the directors and prevent services from working in a "silo-type" configuration.

Now that the context is sketched, we need to look more closely at the specific ways in which the consultant was attributed those tasks and carried them out, and how in doing so he constantly negotiated his authority. By drawing on the field notes we mentioned earlier, we identify some key moments in the unfolding of events. These moments broadly follow a chronological order, from the framing of the mandate to the ending of the assignment. Between these boundaries we focused mainly on controversial and ambiguous moments where, as we mentioned earlier (Latour, 2005, Part I; Callon, et al., 2009) the performance of authority is exacerbated. The chronological order is complemented with a thematic structuration of the analysis, which is probably the most important. After giving particular attention to the framing of the mandate as a formal entitlement of the consultant's authority, we insist on the fact that authority is constantly negotiated in interactions and therefore that there is risk of failure in the performance of authority. We then focus on the figures that the consultant mobilizes in practice to lend weight to his action and assuage this risk of failure, namely people, material artefact, and abstract entities. This theme-based partitioning is used for the sake of clarity, the reality of practice being much fuzzier and the frontiers between the types of figure blurred. 


\section{Analysis}

\section{The mandate as a founding ground for the consultant's authority}

The "framing" of the consulting assignment is a founding ground for the consultant's authority during the mission. At this preliminary stage, the content of his task is defined along with the figure he ought to be acting for. A particular attention should be given to the mandate's constitution. As we saw in the introduction, the institutional position or hierarchical structures, while they must be constantly actualized and negotiated, remain a fundamental source of authority. People may invoke as many figures as they want to establish their authority as the President of France in an official context, they are doomed to fail if they have never been elected as such. The logic is similar in the case of the consultant, who acquires his ability to act as a consultant through the initial mandate that is entrusted to him. That being said, the mandate, contrary to the schematic depictions of the principal-agent model, is neither clear nor purely attributive. It is the ongoing result of an ambiguous and interactive process. In our case, the consultant, Tony, was first called out by a former client of his, Charles, who wanted to discuss a mission for which he needed help. The discussion took place in the hallway of MotherCompany where both men worked. Charles mentioned:

We're starting a restructuring assignment [...].You'd really like a mission like that [...] it is serious stuff; we're really getting into strategic issues. [...] We're putting together a team over there; you'd be overseeing six or seven guys. I need a full-time project head, someone I can trust and who's in charge of getting the music right and doing a major communication job on the restructuring process.

The offer was appealing to Tony, who, however, had to discuss it with the ConsultCorp manager in charge of his staffing. In listening to the client proposal, the later stressed two important points. First, according to him, "Charles has to understand he's buying a ConsultCorp consultant and not you directly; he has to understand we're a team and that there's an important follow-up job done by the managers [...]" The manager pushed forward the collective aspect of the consultant job to make sure Tony intervenes as a representative of ConsultCorp, rather than on his own behalf. Second, he insisted on the fact that "you don't put a guy alone for six months to supervise a restructuration project [...] the assignment looks tricky, and especially ill-framed [...] so you're going to write me down a formal business proposal, we will do the job by the rules and we will commit on something clear". 
In this case, the business proposal is considered as a protection tool for the consultant, where the perimeter of the tasks he will be accountable for is defined formally (and even materially). The source of the consultant's authority is negotiated and encapsulated in the document. In accordance with his understanding of the context of the mission, the consultant had then to "make proposals" to the ConsultCorp manager, who would discuss the final version of the mandate with the client in respect of the hierarchical line. As written in his field notes, the consultant knew little about what the assignment would look like:

Regarding the expected content of the mission, I know little of what Charles needs. I allowed myself to ask him a few questions, but he didn't say much. I know he's meticulous about communication and that it boils down to a classic change management assignment, with important aspects of facilitation, coordination and reporting.

According to the ConsultCorp manager, the client "was mostly concerned with the price and the organization of the assignment". Indeed, Charles didn't want to hire in surplus a ConsultCorp manager because he considered he could directly supervise "his" consultant, for he had a clear notion of his needs. As a good salesman, the manager eventually gave in, but kept supervising the consultant in "hidden time" to "guarantee of the quality of the provided service."

We observe here a strong competition between the ConsultCorp manager and the client to have or maintain control over the consultant. At stake here is also a matter of resources from which Tony will be able to draw, his authority relying on either a network of expert from ConsultCorp or on closeness and strong guidance from his client. According to the ConsultCorp manager, a consultant that would not be managed and backed up by a group with a strong culture and collective skills would be the equivalent of "an interim seconded to do PMO, not a real consultant".

This illustrates that the mandate is a hybrid artifact that is, on the one hand, negotiated between the consultant and his client and, on the other hand, that singly encapsulates the three figures of authority, to which we will return shortly. It is at the same time an abstract entity that represents the contract between the consultant and his client, who sponsors the mission, and a material stratum that stabilizes the relation.

\section{Tensions between clients and negotiation of the consultant's task}

The negotiation of patronage we observed between ConsultCorp manager and Charles was made even more complex when the CEO of EnergyCorp stepped in and turned the dyadic relation into a triadic one. 
As we said, Charles was the "paying client" of the assignment, who signed the contract and paid ConsultCorp bills. However the consultant effectively worked with another person, in our case Gerard, the CEO of the recently bought subsidiary company, EnergyCorp, who was considered by Tony as the "effective" or "operational" client.

Because Tony was to be seconded from the MotherCompany Projects Office to EnergyCorp, Charles organized an interview between Gerard and the consultant. He obviously wanted to be certain that the two could get along before signing the contract. The get-together went well and ended with Gerard explaining to the consultant what he expected from him. As written in the consultant's field notes:

We end up talking about what he expects from me, as the "project manager in charge of the restructuring program." He explains that "Now we need to get in project mode. I need someone to orchestrate [the entire restructuring program], to mobilize my directors, who are going in all directions and lack a global vision. You'll have to give the tempo and delve deeper into issues. You must also be able get people from departments to work on the project." I answer that I don't have an extended knowledge of the craft. "I have worked six months at MotherCompany, I know what P1, $P 2$ and $\mathrm{P}^{2}$ are, but not in a detailed way and I may have blind spots on technical questions." Gerard responds drily: “I don't care at all. For technical skills, we've got all we need internally. In fact, I'll tell you, I prefer that you come in without preconceptions, with your ratios. We need someone to kick the anthill."

Thus, Gerard gave the consultant yet another assignment (or even a set of tasks). At first glance, his instructions happen to be aligned with Charles' vision of the consultant's role. While the consultant is worried about his lack of technical skills he is put in double-bind situation, since his weakness is downplayed, while at the same time both Charles and Gerard "expect [him] to quickly take the leadership of the project." We could say here that Tony is sent to perform a task without being qualified (which is common in consulting practice), and that the very subject of what constitutes appropriate qualities for the assignment is a matter of negotiation, if not disagreement. This doesn't mean however that the consultant is doomed to do a bad job. It does shed light on the complexity of a practice where skills have to be acquired and mobilized on the spot, according to the client's expectations. In our case, this last part is far from being the easiest to achieve, because after a few weeks of work, strong oppositions appeared between Gerard and Charles about the way the consultant should handle his tasks.

\footnotetext{
${ }^{2}$ This is the internal classification for EnergyCorp services.
} 
Gerard had the reputation of being a "bossy", hard to please manager. In order, on the one hand, to make sure the consultant made no mistakes while working on the Projects Office's behalf and, on the other hand, to keep control over the assignment, Charles asked the consultant "to avoid by-passing him and having direct liaison with the CEO." But Tony was positioned in the office right next to the Gerard's, who constantly solicited him to produce scorecards, to audit processes, to lead meetings, and so forth. Trying to deal with Charles's first injunction not to handle direct contacts was almost impossible; at most the consultant would manage to postpone some of Gerard's requests, communicate with Charles and ask him for guidance.

After a few weeks of the consultant's careful juggling with both contradictory mandates, a conflict between the paying and the operational client burst out during a weekly meeting on strategic issues. It all started on the peripheral subject of the redesign of the support functions. Gerard accused Charles of having ignored his instructions in creating a "control manager" position within each operational center of the group. Charles denied it, explaining he had put together a workgroup with relevant directors who decided, collectively, to create this new position. The consultant, who took an important share in these decisions, was initially not even mentioned in the conversation. His involvement in the alleged actions faded away behind what turned out to be a frontal opposition between the two clients. At some point Gerard lost his temper, threw his pencil violently on the table, where it bounced before flying through the room, and he started yelling: "For God's sake, I need a Projects Office to help me, not to decide instead of me. When I take a decision, I refuse that people question it all the time; [...] bloody hell, that's not possible. I don't want control managers in each center; I want a central control management unit [...] centers are not business units but production plants".

At that point, the consultant issue surfaced in the conversation as directly linked to this straightening out episode:

"[...] and where is my project manager that's supposed to be working 100\% [on my restructuration project], to be moving forward on all topics and getting his hands dirty, I never see him, I don't know what he's doing [...] Is that an acceptable situation? Hey, what's all that rubbish supposed to mean?"

Gerard started talking straightforward to the consultant, who had remained silent prior to that: "are you comfortable in this situation? [...] I'm not saying you're not doing anything, I'm saying I have no visibility on what you're doing, it's not clear, what I see is that I have a project manager that's not in my wheel, and that's not going to last any longer."

Despite his proximity with the paying client, the authority of the consultant is directly challenged. In the view of Gerard, the consultant has to be "in his wheel," that his authorized by 
him to act as a legitimate project head of the restructuring process. As a consequence, both Tony and Charles decided to change their strategy. Indeed, when debriefing the meeting, Charles acknowledged to the consultant that Gerard had "the right to be mad if he considers our work not to be visible enough". He thus suggested a complete change of strategy:

[...] ok, now, I want you to stick to [Gerard], I want you to go see him three times a day so that he is aware of everything that happens. Ask him for advice about everything and nothing. I want him to kick you out because you involve him so much. And you are going to be much more aggressive in your relationship with the functional directors. You have to use Gerard. For the reorganization, you send directive emails to them and you put the CEO in carbon copy, we have to hurry the pace [...]

The consultant therefore embarked upon a mission with an ambiguous mandate and with a chain of authority that was not clearly defined. In addition to being torn between ConsultCorp and MotherCompany, Tony found himself further divided between the paying and the operational client. What seemed to be one mandate turned out to be a fractured, contradictory multi-headed beast. If it works as a founding ground for the consultant's authority, in the sense that it gives him "a right to be there" and somehow to act as a consultant, the mandate has to be constantly performed and negotiated according to the situation. No initial framing of the assignment may prevent the consultant from actually performing his task and re-negotiate his authority.

\section{Enacting change through authority: when things don't work out}

If authority has to be constantly negotiated and enacted according to situations, it makes perfect sense that failure often occur. In this section we will describe the difficulties Tony experienced when asserting his authority toward the functional directors.

The relationship between the consultant and the EnergyCorp functional directors was not easy to manage. The competition between Charles and Gerard had a rather negative impact on Tony's positioning in the organization, making it fuzzy and politically controversial. As a result, the consultant had a hard time with the day-to-day establishment of a stable ground on which to stand. A few weeks after his arrival, Gerard asked the consultant to attend a meeting on legal matters with several directors. The transfer and merger of holdings in the context of the group's reorganization was the focus of the discussion.

The participants knew each other well and Tony didn't have the chance introduce himself properly during a round table. The meeting started as if he were not even there. Although he didn't possess much insight on the subject matter, the consultant could rapidly note that the encounter meeting had not been prepared properly and that participants did not know their 
specific contributions. Questions of details were discussed when the general format of the transfer was not yet defined. After a ninety-minute discussion, the participants started to get impatient, and the Administrative and Financial Director, who was leading the talk, threw a quick conclusion: "alright, it's clear for everyone, let us see each other again in a month." At that moment, after having remained quiet thus far, the consultant mentioned to the directors that some elements were unclear to him and that he would be grateful if someone could further explain some aspects of the transaction, the responsibilities of each participants and the planning for forthcoming actions. Surprised by this unexpected sortie, one of the directors replied with an aggressive tone: “excuse me, we haven't been properly introduced, who are you again?" The consultant had his first opportunity to try the introduction Charles and he had elaborated. He replied: "my name is Tony, I'm seconded from the MotherCompany Projects Office to support Gerard in the EnergyCorp restructuring process [...]." Quite unexpectedly, the audience started laughing loudly and each director made a comment: "Only that?"; “The Projects Office? I see! [laughs]" or "And what about us? Are we worthless?" The consultant made excuses about the clumsiness of his introduction, but he had definitely missed the point, and this first encounter would have a negative impact on his authority, especially with the Administrative and Financial Director (henceforth AFD), throughout the rest of the assignment.

The consultant's misadventure with the directors illustrates that he was not given a mandate and authorized once for all. He had to interactionally reiterate and perform again his authorization - and his authority - by invoking people and principles in the name of whom he acts. This is what he attempted to do by positioning himself as acting for MotherCompany to assist Gerard on the restructuration project. However, the directors criticized loudly the fact that the consultant's introduction left no room for them: he did not draw his legitimacy from their collective effort at restructuring the organization, but rather from an entity - MotherCompany that many viewed as foreign to their concerns. The directors sarcastically responded to what was considered an impetuous positioning. Indeed, the consultant's introduction may have given the impression that he was "parachuted" from MotherCompany and that he did not need to find support among the directors themselves. Drawing from patronage figures to act authoritatively among directors was not enough; the consultant would have to find another network of helpers to be effective without turning people against him. Charles would sometimes remind him the need to have "an iron fist in a velvet glove." In other words: "You need to know how to make people understand you are not a threat." We will now describe three types of figures that were mobilized by the consultant to assert his authority: abstract entities, human allies and material artefact. 


\section{Collaborating "for the sake of the organization"}

In a subsequent encounter, the consultant expected the AFD to help him find the financial data necessary to feed the CEO's benchmark indicators. On this occasion, Tony experienced difficulties achieving collaboration with someone who constantly contested his authority.

The consultant wanted the AFD's approval to make sure the scorecards provided Gerard with relevant data that could be tracked throughout the evolution of the company's financial structure. The AFD, though, absolutely refused to collaborate, saying that the consultant's demands were not specific enough, that it wasn't his job to produce this kind of scorecard and that the "value-added of the consultant was not obvious otherwise". He told him to come back with more specific demands from the CEO who was the final recipient of the scorecard. Gerard, in return, would tell the consultant, "talk about it with [the AFD], it's his job." Tony was then put in a middle position, which stressed the existence of a gap between the mandate(s) and their situated enactment. On several occasions, the AFD showed disagreement with the consultant, stating he was only good to "put things in little boxes," that he "had no value-added for the real work" and refusing to share with him information on the projects.

At some point the consultant talked about these difficulties with Gerard, who probably intervened because the AFD came to the consultant's office, very aggressively, and said, “don't try to get between Gerard and his inner circle [...] we know how to play French billiard [use strategy], and if you play this game we will isolate you [...]." After several confrontations, the consultant finally found a common ground with the AFD "for the sake of the restructuring project": he acknowledged he was too demanding and pushing forward, and he agreed to talk to Gerard about the directors being overwhelmed with work; on the other side, the AFD agreed to be more cooperative, and to communicate information. The reconciliation imposed for the consultant to invoke the "common good" of the organization or "the sake of the restructuring project" to engage the AFD to collaborate and overcome a personal opposition.

The conflict with the AFD shows, for its part, that while the consultant considered he was asking for financial information on behalf of Gerard, this understanding was not shared. It is only when the consultant, in a long conversation, invoked the restructuration project itself as a source of common motivation that the AFD agreed to consider that they were both in the same boat.

\section{Enrolling human allies to gain strength}

This opposition between Charles and Gerard was, as we have shown, certainly due to a conflict of patronage. But it was also the result of different interpretations of the consultant's main role in the restructuring process. 
According to Projects Office' director, the consultant had a general coordination and steering role mostly focused on the production of scorecards and the coordination of the board of directors, whose members were "sponsors" of the projects, and their teams in charge of their implementation. He wanted the consultant to build a "helpful relationship" with directors who may have been reluctant to collaborate. He had to be considered as a "resource person," as a key informant who facilitated their tasks without cutting into their merit.

On the other hand, the CEO of EnergyCorp reproached the Projects Office (and the consultant) for being "too abstract, too far from the subjects." He wanted Tony to "get his hands dirty" as said before, and take a share in the implementation of specific projects. This consisted for example in meticulous data cleansing and mining operations, and production of specific tools and deliverables for the people review, the redesign of the organization but also for technical projects related to EnergyCorp services. He also wanted the consultant to push along the directors, whatever the consequences could be in terms of relations.

The consultant, hence, had to "do the splits". To cope on a daily basis with Gerard's requirements and foster his authority on this ground, he mobilized several resources in order to develop the repertoire of the "operational consultant." Bridget was probably the most important one. Bridget was a former quality engineer at EnergyCorp, seconded to help Tony with formalization tasks related to the restructuring program. She became a key piece of the consultant's practice, though, because of her insider knowledge on the organizational and technical facets of the job. She could answer two of Tony's most pressing questions: who is doing what for which company in the group, and what are precisely the EnergyCorp's services and their distribution among plants? Quickly, they became inseparable. The consultant would take her to key meetings as a sort of "insider expert" who could fill in methodological propositions with actual names, sites and technical descriptions.

Yet, Tony also realized that Bridget was somehow still marked by a former low level image, and that if she could be helpful as an insider, he also needed to mark his difference from her. Charles and the consultant dealt with that matter when deciding that Bridget should not introduce Tony to EnergyCorp directors and middle managers for "she could harm his image." Both men knew the importance of getting the right person to do the introduction and invoking the right entities in doing it. They felt that Bridget's lower status in the company could imply that the consultant's authority was equally lower. They also found an agreement on a "typical" introduction line Tony could use with insiders. The pitch would be the following: "I'm from the MotherCompany general management to support Gerard in the EnergyCorp restructuring 
process." We can see here that the patronage of both Charles and Gerard is acknowledged as a resource for authority.

What is interesting with Bridget's position relatively to the consultant is that she played both the part of a helper and, in spite of herself, that of an antagonist. By providing the consultant with information about EnergyCorp's staff and activities, she feed him with auxiliary knowledge that turned him into a competent player. However, because of her status in the company, the consultant's association with her could also be perceived as an impediment to his authority. Tony was thus caught up in a dilemma: he both required Bridget's help and had to keep her at bay. Bridget was not a well-defined "resource" that he could draw from. It was Tony's ability to relate to her, to share is actions with her - i.e. the performance of that association - in a way that was consistent with his own position within a complex configuration of agency, that would constitute Bridget either as a helpful assistant or as a hindrance.

\section{Producing insideness or abstraction: the complex role of methodology}

Despite Bridget's help, the consultant still had difficulties mastering the large amount of information needed to coordinate the restructuring process. He however found another resource in doing "auditing assignments" on the field. In the jargon of Tony's consulting practice, audits involve several "methodology" tools, i.e. standardized tools and documents that provide guidelines for action. These tools, but also the audit report, would become important figures he could draw from to assert his authority.

Charles insisted very much on Tony getting involved in audits, because it was a way to get closer to field workers and thus to overcome the strong dividing line that existed, even inside the company, between functional and operational workers. Interestingly, it was Charles, who initially thought Tony should focus on more abstract, high-level work, who was now insisting on the importance of getting close to the field. In fact, he considered them as two faces of the same coin. The director of the Projects Office explained:

You'll go three days on the premises with [some technical expert from MotherCompany] to do the energy production audit. Don't worry; he'll be doing the interviews. I want you to listen and understand, and to take notes. You'll be in charge of writing down everything and producing a synthetic report to Gerard.

The consultant followed the expert during three days to several plants around the country. Tony's insecure writing of the first hours became more assured as he could observe and imitate insiders, cross-check and compare information, formalize and synthetize. On the field, the 
consultant could acquire a lot of first-hand information, and witness directly what was going on, and record his observations in notes and various documents.

The effects of this auditing assignment were even more obvious later on, at the head office, when dealing with functional people on the restructuration process. Tony was able to use the audit report as a proof of his technical awareness, as an "example bank" to insist on his indepth, situational knowledge when, for example, talking about organizational design and logistics. He could describe several cases of plant control and administration, and use the stories of "the men on the field" as a strong semantic reference. In this case the "example bank" did not rely on outside knowledge in the sense of former experiences acquired by the consultant in different environments. It resulted from the ability to use an exploratory methodology that drew on the organization's existing knowledge and recirculated it. Because of his ability to move close to the field and then work on various tasks in the functional services, the consultant soon could be "the insider" even to insiders and assert his authority through this feature.

However, such kind of field-oriented knowledge had less impact on the board of directors, who valued "outside" information and formal methodologies, rather than operational references. The consultant therefore had to rely on other resources, such as those provided by Charles' team of internal consultants at MotherCompany. This material was of particular interest in projects such as the information system redesign.

EnergyCorp's IT system was obsolete and had a poor software interface. As part of the restructuring process, it was decided to change the whole system. To document this project and come up with solutions, the consultant abundantly used experience feedback from one of MotherCompany's other subsidiaries, which handled similar services in the same sector. He could then draft detailed specifications for the new system and draw from outside experience to suggest improvements to the technical control and invoicing processes.

At some point, however, an opposition between Charles and Gerard surfaced again on this subject. The CEO had two options regarding the evolution of EnergyCorp's IT system. The first was to deploy MotherCompany's own system in the subsidiary, which would be done intragroup by the IT services, but was surprisingly very expensive. The second consisted in consolidating the current system by buying upgrades on the market and managing the project internally. Despite no particular involvement of the Projects Office in the first solution, Gerard considered any attempt to use MotherCompany knowledge a tactic from Charles to gain control over EnergyCorp. He therefore refused any proposal made by the consultant that relied on MotherCompany material. He asked the consultant to make a feasibility study for both projects 
relying on ConsultCorp knowledge with insight on market ratios. The consultant, with the help of his manager, thus drew from ConsultCorp best practices despite their lack of sectorial relevance.

We can see here that the conflict of authority between the two directors pushed the consultant to adapt his stance according to the situation and invoke different networks of technical authority. In doing so, he mobilized several methodological resources that reinforced his ability to get the task done. We see that authority is not considered as rhetoric but as an objective capability to act with a network of material helpers, sometimes closer to the field, sometimes closer to abstraction levels, according to the needs and the room for manoeuvre. Concretely, the consultant could alternatively invoke knowledge either from the operational field or from formalized models, either from MotherCompany IT expertise or from ConsultCorp. Choosing which repertoire to tap into also changed the consultant into a different person by locating him on either side of a dividing line: he could be a "true insider" or a "manager"; he could be a MotherCompany accomplice or a ConsultCorp expert.

\section{Who's acting on whose behalf? Writing up a work plan}

As a conclusion to the analysis section, we should present an important limitation of the practice of attributing one's actions to other figures in order to gain authority. We have seen that the success of the consultant's work hinged on his ability to share his actions with others. In a sense, his work was the most efficient when it was seamlessly integrated into the common project. But this form of integration also made his contribution invisible, which may have, as we will see now, downside effects.

Given the complex network of appraisers who had to evaluate his work, Tony realized in a bitter way that no one seemed to notice the workload he was coping with. He asked for advice to his manager at ConsultCorp, who answered:

[...] you'll do a work plan... If you tell me you work too much, I don't care, I don't see it. My friend, you're a consultant, you signed for it. We need to be able to establish as a fact that you work too much. [...] In addition, if each time your client throws a stone at you, you catch it and keep on floating, he has no reason to stop throwing them. [...] We need to find a way of saying "stop" and make factual your work load.

What was at stake, then, was the visibility of the consultant's work. He needed to make apparent his involvement in his own actions, and "factualize" the amount of work he handled directly. Tony started writing up a work plan where he kept track of and quantified his contribution to the project. Charles thought it was indeed a good idea, because he would then be 
able to use the measures to convince Gerard of the need to "beef up the Projects Office team." He wants to have tools to show him what his office does for him and how "the Projects team is $200 \%$ involved."

That the consultant got "under the water" and needed to write a document where he could describe and quantify his work is interesting for it shows that the recognition of the consultant's work can only take place if there are tools to make his effort apparent. This leads to a third feature, which is the paradoxical nature of action within organizations: while the consultant needs to share his action with others in order to act legitimately, he risks - and it happened here indeed - hiding his own involvement in actions so effectively that he is not acknowledged at all as their author. The consultant - not unlike other organizational members - therefore has to walk on a thin line, attributing his actions to a variety of entities, as we saw above, but never forgetting that he needs, on the other side, tools to keep track of his own work and remind his appraisers that, on the bottom line, he is the one doing the job. Charles is also acutely aware of this, as he piggybacks on the consultant's work plan to make the contribution of the Projects Office visible.

Finally, after a phase of six months, Gerard had to decide if he would keep working with the Projects Office. But at this time, the conflict of authority between the CEO and Charles was becoming too important to ignore. Gerard told the consultant he did not want to maintain this configuration of work and he said to him: "it doesn't belong to us enough, I mean the Projects Office. I want people to be in my wheel, but I know you understood that". Charles was disappointed by the decision, which he felt was unfair, but accepted it and allowed the consultant to suggest to Gerard to work directly with him, without the help of the Projects Office. Gerard declined the offer because the consulting firm, ConsultCorp, had a team working at MotherCompany's headquarters. Until the last moment, therefore, the tension regarding the "configuration" of the mandate was important. Both Gerard and Charles understood quite well this was not only a matter of being able to give orders to the consultant, but that the consultant's work was crucial in presenting their respective organizations - EnergyCorp or the Projects Office - as active in the restructuration project, as his work could also be appropriated and showcased as their own. Gerard's ultimate refusal to work with ConsultCorp, on the pretext that they had a team at MotherCompany, can also be read as a fear to have "his" work being attributed to the latter, through the intermediary of the consulting firm. 


\section{Discussion}

In this case, we observed how Tony was indeed confronted with the messiness of action during his consulting assignment. Far from being a clear course of events where the roles and tasks are settled according to a plan, the practice of consulting is a constant struggle to assert authority, to build up competency and to circulate among clients with conflicting interests. In fact, one could say that it is this very confusion that opened gaps where the consultant could find margins of action and draw from seemingly competing repertoires. Doing that, however, supposes that consulting is not a stable, well-defined practice, but rather a performance.

Our ethnographic data, by showing a story of "how the job gets done" (Orr, 1996), goes along several recent studies on client/consultant relationship that have led to a rather dynamic understanding of consulting practice which avoids choosing between a critical or functional stance. For example, Sturdy (2009b) considers management consulting from the perspective of the many boundaries - including cognitive ones - that are negotiated between individuals and especially between consultants and their clients. The ability to operate a knowledge transfer hinges on the establishment of an optimal distance: parties must be far enough apart for there to be something to learn from each other, but close enough for there to be a common ground on which the learning process may rely. Czarniawska and Mazza (2003), on their part, use the concept of "liminality" to describe the work of consultancy as an in-between space, where routines and habitual work is replaced by new rituals and practices. In other words, consultancy is increasingly being viewed not as a static set of transactions held in a well-defined space, but rather as both the cause and the product of a series of complex relations and interactions. In her study of management consultants' discourse, Whittle (2008) also pleads for a more complex understanding of consultants' rhetoric. While consultants' rhetorical work is often associated with the funneling of management fashions, the author shows that, on the contrary, consultants make a strategic use of, in this case, the discourses of flexibility or work-life balance, which are constantly re-interpreted and re-articulated in line with the consultant agenda.

Our analysis shows that Tony embarked upon a mission with an ambiguous mandate resulting from a conflict of patronage and with a chain of authority that was not clearly formalized. However, the letter of engagement, and the negotiation it embodied (as unclear as it may have been) constituted a first source of authority that "authored" him as legitimately acting in the name of both the MotherCompany Projects Office and ConsultCorp. The role of the engagement letter cannot be downplayed, as it was, ultimately, the figure that established that Tony could or had to act as a consultant (as opposed to any other role). In spite of this empirically 
observed crucial role, the letter of engagement is also a figure like any other - it combines a artifactual dimension (the document as such) with an abstract entity (the agreement it embodies) and the people whose positions it represents.

The ambiguity of the agreement, paired with the ability to renegotiate it as a figure, meant that Tony was put in a position where he could permanently "do the splits" between contradictory requirements, enrolling insider and using methodology to get closer to the field, providing outside knowledge to overcome political conflicts. The understanding of authority we presented in the case, then, cannot be reduced to a well-planned sequence of events, procedures or rituals, and even less so to a resource from which the consultant can draw. It is rather a relational knowledge, an ability to mobilize in the course of actions the appropriate network of adjuvants that will foster its ability to act. The authoritative consultant knows how to associate with a sociotechnical network, where people, documents and tools, but also more abstract beings - experience, education and organizations - can lend weight to his or her actions, but also authorize them and inscribe them in a sensible mandate. Finally, as the consultant's mission came to a conclusion, we observed a subtle and paradoxical aspect of authority: the case showed that the consultant, in order to act legitimately, must attribute part of his actions to the entities in whose name he acts; however, he must also have means to show, "objectively," that he is also the author of the actions in question, otherwise no assessment can take place.

Cooren (2008, 2010), borrowing from the work of David Goldblatt (2006), introduced the metaphor of ventriloquism to the study of organizations. With respect to the paradoxical necessities of both showing and hiding one's work, our consultant is indeed caught up with the same contradictory injunctions as many puppeteers. Ventriloquism may be the art of hiding one's own speech by attributing it to a dummy, but the artist must continuously remind the audience that the feat is, in fact, his own work (for example by introducing staged blunders). Otherwise, the audience could believe the dummy is actually talking "by itself" and would not understand what the performance consists in. Tony, in the same way, had to attribute his agency to a variety of entities in order to act authoritatively as a consultant and perform his job. He indeed succeeded so well that, in fact, people did not realize he was doing the job, so much that he had to come up with a strategy in order to keep track and display his own involvement in his own work.

In positioning himself as acting for or on behalf of a variety of other actors, both human or not (see on that Latour, 1999), thereby mobilizing them to lend weight to his actions (Cooren, 2010), we saw how Tony managed to locate himself inside or outside different organizations. As Ellis and Ybema (2010, p. 279) point out, people in organizations are "boundary bricoleurs," and consultants are no exception. By drawing from "repertoires," they can establish the boundaries 
that matter. Sturdy and Wright (Sturdy \& Wright, 2011), on their part, have shown the important role played by the client-consultant relationship in negotiating organizational boundaries. The position of the consultant inside or outside the client organization is important in defining his or her ability to contribute knowledge (Sturdy, Clark, Fincham, \& Handley, 2009a). In our view, both the client-consultant relationship and the ability to make a contribution hinge on authority. This brings us to what may be one of the most interesting elements the observation of the consultant's experience teaches: the relationship between authority and the constitution or reaffirmation of an inside / outside divide. The consultant's six-month mission can be read, to a large extent, as an attempt to establish his authority and his ability to act. He did so, as we saw, by invoking various entities - people or sets of knowledge, for instance - that are tied to an organization, whether EnergyCorp, MotherCompany, the Projects Office or ConsultCorp. The consultant thus dynamically located himself within those organizational spaces. As those boundary performances were discussed and contested, the restructuration project itself was being located on either part of the divide thus instituted. The example of the IT system update is especially interesting in this sense. While the consultant initially thought he would be able to speak authoritatively by comparing EnergyCorp's IT situation with other MotherCompany subsidiaries, it turned out that his positioning as a "MotherCompany accomplice" triggered a reaction to relocate EnergyCorp's IT as a project that should be dealt with internally. Besides, we observed that the consultant does not only navigate through the boundaries of formal organizations. His assertions of authority also reveal the existence of borders and groups within a single organization, as is the case when the consultant, coming back from auditing production plants, could display an acute technical knowledge, which made him an "insider" among functional employees, but did not impress directors, who, the consultant learned, valued more abstract formal knowledge over "field" experience.

\section{Conclusion}

The ethnographic study of the performance of authority during a consultancy mission we presented teaches several things. First, we learned that (a) authority, while it may correspond to features of the individual (education, expertise, social position), needs to be made present again and performed in each interaction; (b) that no simple mandate can be given once and for all; it is in fact renegotiated by the consultant in the course of his or her mission; (c) that the consultant receives those mandates from multiple clients, who may be so many sources to his authority; (d) that performing authority consists in attributing one's action to further authoritative figures, 
which may be people, artifacts or abstract entities; (e) therefore, that it can be properly performed, but that there is also a risk of failure; and finally (f) that, as a consequence, those entities are made present in interaction as they are being successfully mobilized as sources of authority: in other words, that one of the ways in which organizations, their boundaries, their rules and their principles are made present, is through their mobilization in situations where authority is being questioned.

The interactional mobilization of authority figures, however, is not only a strategic move, as some may be tempted to criticize. It is a necessity, for it is in his relation with those other entities that the consultant is authored as competent and authorized. However, if he wants people to recognize him as competent, he cannot attribute his actions entirely to the figures that he stages as driving him to action. The risk is that they may be recognized as the sole authors of action. The consultant must therefore strike a delicate balance between heteronomy and autonomy, between authority and idiosyncrasy - that is to say acting on his own and acting for other entities.

Further research based on the intuitions developed here could consist in more crossthematic studies that do not view the organization as a unitary space where events and phenomena take place (authority, conflict, culture and so forth) but rather as both an ingredient and an outcome of those phenomena. In other words, describing authority as taking place within the organization overlooks the fact that the organization (and whether we are within or outside it) is also being negotiated as authority (or conflict, or culture, or other phenomena) is being performed.

Research on the intersections of authority and consulting, as we have said, is still scarce, and that could be the case because of the lack of theoretical frameworks that provide concrete observational strategies and analytical tools for the study of this particular phenomenon. Without claiming that our proposal is the only possible one, and while we acknowledge that access to consultancy missions is difficult, we wish that this paper may serve as an inspiration for further theoretically solid and empirically grounded research. Hopefully, these will offer new approaches to the study of authority in consultancy settings, and, possibly, to authority in organizations more generally.

To practitioners, this paper points out that authority should not be taken for granted and that it may be a crucial issue in the conduct of consultancy missions. The ambiguity of mandates and the multiplicity of clients, while being sources of uncertainty, are at the same time elements on which the consultant may draw to lend weight to his or her authority. This is done by showing how actions are shared with those elements and are, therefore, authorized by them. More broadly, the perspective that is set forth in this paper points to the importance of communication and 
interaction in the establishment of the consultant's authority, which has to be re-established continuously.

\section{References}

Aghion, P., \& Tirole, J. (1997). Formal and Real Authority in Organizations. Journal of Political Economy, 105(1), 1-29.

Ailon, G. (2006). What B Would Otherwise Do: A Critique of Conceptualizations of 'Power' in Organizational Theory. Organization, 13(6), 771-800.

Alvesson, M. (1996). Communication, power and organization. Berlin / New York: Walter de Gruyter.

Alvesson, M., \& Johansson, A. W. (2002). Professionalism and Politics in Management Consultancy Work. In T. Clark \& R. Fincham (Eds.), Critical Consulting: New Perspectives on the Management Advice Industry (pp. 228-246). Oxford: Blackwell.

Alvesson, M., Karreman, D., Sturdy, A., \& Handley, K. (2009). Unpacking the client(s): constructions, positions and client-consultant dynamics. Scandinavian Journal of Management, 25(3), 253-263.

Anderson, L. (2006). Analytic Autoethnography. Journal of Contemporary Ethnography, 35(4), 373-395.

Armbrüster, T. (2006). The economics and sociology of management consulting. Cambridge ; New York: Cambridge University Press.

Baker, G., Gibbons, R., \& Murphy, K. J. (1999). Informal authority in organizations. Journal of Law, Economics, and Organization, 15(1), 56-73.

Barnard, C. I. (1938). The functions of the executive. Cambridge, Mass.,: Harvard University Press.

Bendix, R. (1947). Bureaucracy: The Problem and Its Setting. American Sociological Review, 12(5), 493-507.

Bendix, R. (1956). Work and authority in industry: ideologies of management in the course of industrialization. New York,: Wiley.

Benoit-Barné, C., \& Cooren, F. (2009). The Accomplishment of Authority Through Presentification. Management Communication Quarterly, 23(1), 5-31.

Bergström, O., Hasselbladh, H., \& Kärreman, D. (2009). Organizing disciplinary power in a knowledge organization. Scandinavian Journal of Management, 25(2), 178-190.

Blau, P. M. (1963). The dynamics of bureaucracy : a study of interpersonal relations in two Government agencies (Rev. 2d ed.). Chicago: University of Chicago Press.

Brummans, B. H. J. M. (2006). The Montréal School and the question of agency. In F. Cooren, J. R. Taylor \& E. J. Van Every (Eds.), Communication as organizing: Empirical and theoretical explorations in the dynamic of text and conversation (pp. 197-211). Mahwah, NJ: Lawrence-Erlbaum.

Bryman, A. (2004). Social research methods (2nd ed.). Oxford ; Toronto: Oxford University Press.

Callon, M., Lascoumes, P., \& Barthe, Y. (2009). Acting in an uncertain world: an essay on technical democracy. Cambridge, MA: MIT Press.

Callon, M., \& Muniesa, F. (2005). Peripheral Vision. Organization studies, 26(8), 1229-1250.

Carr, A. (1998). Identity, Compliance and Dissent in Organizations: A Psychoanalytic Perspective. Organization, 5(1), 81-99. 
Casey, C. (2004). Bureaucracy Re-Enchanted? Spirit, Experts and Authority in Organizations. Organization, 11(1), 59-79.

Castor, T., \& Cooren, F. (2006). Organizationsas Hybrid forms of Life: The Implications of the Selection of Agency in Problem Formulation. Management Communication Quarterly, 19(4), 570-600.

Certeau, M. d. (1990). Arts de faire. Paris: Gallimard.

Clark, T., \& Salaman, G. (1996). The Management Guru as Organizational Witchdoctor. Organization, 3(1), 85-107.

Cooren, F. (2008). The selection of agency as a rhetorical device: Opening up the scene of dialogue through ventriloquism. In E. Weigand (Ed.), Dialogue and Rhetoric (pp. 23-37). Amsterdam: John Benjamins.

Cooren, F. (2010). Action and Agency in Dialogue: Passion, Ventriloquism and Incarnation Amsterdam/Philadelphia: John Benjamins.

Cooren, F. (Ed.). (2007). Interacting and Organizing: Analyses of a Management Meeting. Mahwah, N.J.: Lawrence Erlbaum Associates.

Crawford, L. (1996). Personal ethnography. Communication Monographs, 63(2), 158-170.

Crozier, M., \& Friedberg, E. (1980). Actors and systems : the politics of collective action. Chicago: University of Chicago Press.

Czarniawska, B., \& Mazza, C. (2003). Consulting as a liminal space. Human relations, 56(3), 267.

Dean, K., \& Massumi, B. (1992). First \& last emperors : the absolute state and the body of the despot. Brooklyn, N.Y.: Autonomedia.

Dessein, W. (2002). Authority and Communication in Organizations. The Review of Economic Studies, 69(4), 811-838.

Dixon, M. A. (2007). Transforming Power: Expanding the Inheritance of Michel Foucault in Organizational Studies. Management Communication Quarterly, 20(3), 283-296.

Ellis, N., \& Ybema, S. (2010). Marketing Identities: Shifting Circles of Identification in Interorganizational Relationships. Organization studies, 31(3), 279-305.

Fincham, R., \& Clark, T. (2002). Introduction: The Emergence of Critical Perspectives on Consulting. In T. Clark \& R. Fincham (Eds.), Critical Consulting: New Perspectives on the Management Advice Industry (pp. 1-20). Oxford: Blackwell.

Forest, J., Mageau, G. A., Sarrazin, C., \& Morin, E. M. (2011). "Work is my passion": The different affective, behavioural, and cognitive consequences of harmonious and obsessive passion toward work. Canadian Journal of Administrative Sciences / Revue Canadienne des Sciences de l'Administration, 28(1), 27-40.

Ganesh, S. R. (1978). Organizational Consultants: A Comparison of Styles. Human relations, 31(1), 1-28.

Garfinkel, H. (1967). Studies in ethnomethodology. Englewood Cliffs, N.J.,: Prentice-Hall.

Gherardi, S. (2000). Practice-Based Theorizing on Learning and Knowing in Organizations. Organization, 7(2), 211-223.

Giddens, A. (1984). The constitution of society : outline of the theory of structuration. Cambridge [Cambridgeshire]: Polity Press.

Gideon, K., Barley, S. R., \& Evans, J. (2002). Why Do Contractors Contract? The Experience of Highly Skilled Technical Professionals in a Contingent Labor Market. Industrial and Labor Relations Review, 55(2), 234-261.

Goffman, E. (1969). The presentation of self in everyday life. London,: Allen Lane.

Golant, B. D., \& Sillince, J. A. A. (2007). The Constitution of Organizational Legitimacy: A Narrative Perspective. Organization studies, 28(8), 1149-1167.

Goldblatt, D. (2006). Art and ventriloquism. London / New York: Routledge.

Goodall, H. L. (2000). Writing the new ethnography. Walnut Creek: AltaMira Press. 
Grossman, S. J., \& Hart, O. D. (1983). An Analysis of the Principal-Agent Problem. Econometrica, 51(1), 7-45.

Harré, R., Moghaddam, F. M., Cairnie, T. P., Rothbart, D., \& Sabat, S. R. (2009). Recent Advances in Positioning Theory. Theory \& Psychology, 19(1), 5-31.

Hoogenboom, M., \& Ossewaarde, R. (2005). From Iron Cage to Pigeon House: The Birth of Reflexive Authority. Organization studies, 26(4), 601-619.

Jackson, B. G. (1996). Re-Engineering the Sense of Self: the Manager and the Management Guru. Journal of Management Studies, 33(5), 571-590.

Julian, J. (2008). How project management office leaders facilitate cross-project learning and continuous improvement. Project Management Journal, 39(3), 43-58.

Kahn, W. A., \& Kram, K. E. (1994). Authority at Work: Internal Models and Their Organizational Consequences. The Academy of Management Review, 19(1), 17-50.

Kuhn, T. (2008). A communicative theory of the firm: Developing an alternative perspective on intra-organizational power and stakeholder relationships. Organization Studies, 29(8-9), 1227-1254.

Kuhn, T., \& Lee Ashcraft, K. (2003). Corporate Scandal and the Theory of the Firm. Management Communication Quarterly, 17(1), 20-57.

Kvale, S. (1996). InterViews: An Introduction to Qualitative Research Interviewing. Thousand Oaks, CA: Sage.

Latour, B. (1986). The Powers of Association. In J. Law (Ed.), Power, Action and Belief. A new sociology of knowledge? (pp. 264-280). London: Routledge \& Kegan Paul.

Latour, B. (1996). On Interobjectivity. Mind, Culture, and Activity, 3, 228-245.

Latour, B. (1999). A Collective of Humans and Nonhumans: Following Daedalus's Labyrinth Pandora's hope : essays on the reality of science studies (pp. 174-215). Cambridge, MA: Harvard University Press.

Latour, B. (2005). Reassembling the social : an introduction to actor-network-theory. Oxford ; New York: Oxford University Press.

Law, J., \& Hassard, J. (1999). Actor network theory and after. Oxford England ; Malden, MA: Blackwell/Sociological Review.

Lindblom, C. E. (1959). The Science of "Muddling Through". Public Administration Review, 19(2), 79-88.

Lounsbury, M., \& Carberry, E. J. (2005). From King to Court Jester? Weber's Fall from Grace in Organizational Theory. Organization studies, 26(4), 501-525.

Meunier, D., \& Vasquez, C. (2008). On Shadowing the Hybrid Character of Actions: A Communicational Approach. Communication Methods and Measures, 2(3), 167 - 192.

Morgan, G. (1986). Images of organization. Beverly Hills: Sage Publications.

Mumby, D. K. (1988). Communication and power in organizations : discourse, ideology, and domination. Norwood, N.J.: Ablex Pub. Corp.

Mumby, D. K. (1998). Organizing Men: Power, Discourse, and the Social Construction of Masculinity(s) in the Workplace. Communication Theory, 8(2), 164-183.

Muniesa, F., Millo, Y., \& Callon, M. (2007). An introduction to market devices. The Sociological Review, 55, 1-12.

Murphy, A. G. (1998). Hidden Transcripts of Flight Attendant Resistance. Management Communication Quarterly, 11(4), 499-535.

Nelson, R. E. (1993). Authority, Organization, and Societal Context in Multinational Churches. Administrative Science Quarterly, 38(4), 653-682.

Orr, J. E. (1996). Talking About Machines: An Ethnography of a Modern Job. Ithaca, NY: ILR Press.

Richardson, L. (2005). Writing: A method of inquiry. In Y. S. Lincoln \& N. K. Denzin (Eds.), Turning points in qualitative research: trying knots in a handkerchief (pp. 379-396). Lanham, MD: Rowman \& Littlefield. 
Richardson, L., \& Lockridge, E. (1998). Fiction and Ethnography: A Conversation. Qualitative Inquiry, 4(3), 328-336.

Satow, R. L. (1975). Value-Rational Authority and Professional Organizations: Weber's Missing Type. Administrative Science Quarterly, 20(4), 526-531.

Schein, E. H. (1999). Process consultation revisited : building the helping relationship. Reading, MA: Addison-Wesley.

Singh, R., Keil, M., \& Kasi, V. (2009). Identifying and overcoming the challenges of implementing a project management office. European Journal of Information Systems, 18(5), 409-427.

Sturdy, A., Clark, T., Fincham, R., \& Handley, K. (2009a). Between Innovation and Legitimation - Boundaries and Knowledge Flow in Management Consultancy. Organization, 16(5), 627-653.

Sturdy, A., Clark, T., Fincham, R., \& Handley, K. (2009b). Management consultancy: boundaries and knowledge in action. Oxford/New York: Oxford University Press.

Sturdy, A., \& Wright, C. (2011). The active client: The boundary-spanning roles of internal consultants as gatekeepers, brokers and partners of their external counterparts. Management Learning, 42(5), 485-503.

Suchman, L. (1987). Plans and situated actions : the problem of human-machine communication. Cambridge [Cambridgeshire]; New York: Cambridge University Press.

Taylor, J. R., \& Van Every, E. J. (2000). The emergent organization : communication as its site and surface. Mahwah, N.J.: Lawrence Erlbaum Associates.

Taylor, J. R., \& Van Every, E. J. (2011). The situated organization: Studies in the pragmatics of communication research. New York, NY: Routledge.

Taylor, J. R., \& Van Every, E. J. (forthcoming). When organization fails: An inquiry into the constitutive role of authority. New York: Routledge.

Tyre, M. J., \& von Hippel, E. (1997). The Situated Nature of Adaptive Learning in Organizations. Organization Science, 8(1), 71-83.

Weber, M. (1968). Economy and society: an outline of interpretive sociology. New York: Bedminster Press.

Whittle, A. (2008). From Flexibility to Work-Life Balance: Exploring the Changing Discourses of Management Consultants. Organization, 15(4), 513-534.

Williamson, O. E. (1996). Efficiency, Power, Authority and Economic Organization. In J. Groenewegen (Ed.), Transaction Cost Economics and Beyond (pp. 11-42). Dordrecht, The Netherlands: Kulwer.

Wright, C. (2009). Inside Out? Organizational Membership, Ambiguity and the Ambivalent Identity of the Internal Consultant. British Journal of Management, 20(3), 309-322. 